\title{
SOCIAL MEDIA ACCOUNT AS AN OBJECT OF VIRTUAL PROPERTY
}

by

KATERYNA NEKIT

This article analyzes the concept of virtual property as well as the legal nature of social media accounts to explore whether these can be considered objects of property, in particular, of virtual property rights. It examines the essence of virtual property and reveals the specifics of owner's powers regarding to digital assets. It also specifies what kind of objects should be treated as digital assets. The technical and legal nature of a social media account are analyzed to reveal whether the latter can be considered as "possession" in terms of Protocol No. 1 to the Convention for the Protection of Human Rights and Fundamental Freedoms. Some legal issues regarding to the use of a social media account including the division of rights to business accounts and inheritance of social media accounts are investigated. The approaches in various countries to the problem of determination of the post-mortem fate of digital assets are analyzed, and a unified tendency to consider social media accounts as part of the estate transferred to the heir is revealed. The conclusion is drawn that the extension of the property regime to social media accounts could ensure an appropriate legal protection of users' rights.

\section{KEY WORDS}

Account, Digital Assets, Inheritance, Possession, Social Media, Users, Virtual Property

\section{INTRODUCTION}

The term "virtual property" has emerged in the context of attempts to identify approaches to the legal regulation of relationships associated 
with the so-called Massively Multiplayer Online Games (MMOG), the rapid development of which no longer allowed to leave this issue aside. One of the first works to mention virtual property is a study by E. Castronova, who conducted a thorough economic analysis of MMOG Norrath. His analysis revealed striking statistics: 40,000 players were registered in the game, about 12,000 of them considered this place their permanent home; the average user of the game spent approximately 4 hours a day or more than 20 hours a week in the game; the gross domestic product of the game was estimated at USD 135 million; the value of the domestic currency in the exchange markets was approximately USD 0.0107, which exceeded the value of the yen and lira. ${ }^{1}$

The idea of virtual property that arose with respect to virtual items in online gaming has gradually gained a broader interpretation and extended to other types of virtual assets. Today, virtual property is considered to encompass not only in-game objects and avatars, but also domain names, URLs, eBooks, tickets, email accounts, social media accounts, websites, chats, bank accounts, cryptocurrencies and more. ${ }^{2}$

One of the most popular objects among listed is social media account. It is difficult to find a person who has no registration in at least one social network. The popularity of social media accounts alongside with gaps in legislative regulation of those create a huge amount of practical issues referred to the use of social media accounts. Considering not only moral, but also sometimes significant economic value of social media accounts, it is obviously necessary to provide an appropriate protection of the users' rights, preferably on the legislative level. A possible ground for such protection could be the recognition of social media accounts as a kind of virtual property, which in its turn should be qualified as a specific type of ownership.

\section{THE CONCEPT AND ESSENCE OF VIRTUAL PROPERTY}

According to J. Fairfield, virtual property is inherently a code that was designed to "act more like land or mobility than ideas". Such code can be

Castronova, E. (2001) Virtual worlds: a first-hand account of market and society on the Cyberian Frontier. CESifo Working Paper Series, 618, pp. 1-40.

2 Fairfield, J. (2005) Virtual property. Boston University Law Review, 85, pp. 1047-1102. [online] Available from: https://ssrn.com/abstract=807966 [Accessed 26 April 2020]; Palka, P. (2017) Virtual property: towards a general theory. PhD. Florence: European University Institute, pp. 148-160. 
considered virtual property if it meets three characteristics: rivalrousness, persistence, interconnectivity. ${ }^{3} \mathrm{Ch}$. Blazer in his research proposes his own definition of virtual property. In his view, virtual property is a persistent computer code stored by a non-remote resource system, where one or more persons are empowered to control the computer code, including the removal of all other persons. ${ }^{4}$ To the characteristics of the code that allows us to consider it as virtual property, proposed by J. Fairfield, Ch. Blazer suggests adding two more features: the presence of the secondary market and the value added by the user. ${ }^{5}$ Gr. Lastowka and D. Hunter, describing virtual property in online games, view it as database records hosted on a server that allow a participant's computer monitor to display images already present within the software. ${ }^{6}$ DaKunha proposes similar to J. Fairfield's definition of virtual property: virtual property is a software code designed to behave as if it had the qualities of the physical, belonging to the material world, movable things or parts of reality.

These concepts focus on defining what should be considered as virtual property. In fact, we are talking about virtual property as an object of legal relations. However, obviously, there will be a right to this kind of property, which can be defined as a virtual property right. There is a need to study the nature and characteristics of virtual property as a special kind of right.

To determine the nature of virtual property, it is necessary to dwell on the starting points of the categories of "property" and "property right". The attention should be paid to the main point, while characterizing virtual property, that is the possibility of the existence of a right of ownership of incorporeal things.

Without claiming to be original, let us turn to Roman private law to study this issue. In the context of this study the division of things (res) into corporeal (res corporales) and incorporeal (res incorporales), proposed by the Romans, is of particular importance. According to Gaius, corporeal things are those that, by their nature, can be visible, such as earth, slave, clothing; incorporeal things are those that cannot be touched, but they exist

\footnotetext{
Op. cit., p. 1049.

Blazer, Ch. (2006) The five indicia of virtual property. Pierce Law Review, 5, p. 141.

Op. cit., p. 142.

6 Lastowka, G. and Hunter, D. (2004) The laws of the virtual worlds. California Law Review, $92(1)$, p. 40.

7 DaCunha, N. (2010) Virtual property, real concerns. Akron Intellectual Property Journal, 4 (1), p. 42 .
} 
under the law, such as inheritance, usufruct or obligations. ${ }^{8}$ Modern legal systems of the world to one degree or another follow this approach. Thus, in the Anglo-American legal tradition, ownership is usually interpreted quite widely. It is defined as a "bunch" or a set of rights or expectations in movable and immovable things that are protected from third parties, including the state. ${ }^{9}$ Such rights include the right to use, own, remove third parties, and alienate things. "Things" are also interpreted quite broadly and include land rights, movable and incorporeal things. ${ }^{10}$ An important difference of the Roman-Germanic legal tradition is the distinction between property as such and things. The concept of "thing" most often narrows and is limited only to bodily objects. For instance, the German Civil Code (BGB) restricts the objects of ownership only to bodily things. According to para. 90 of the Civil Code of Germany, things in terms of law are bodily objects. $^{11}$

Despite the fact that Ukraine is a country of Roman-Germanic legal tradition, the approach enshrined in Ukrainian legislation on things is different. The Ukrainian law accepts that some incorporeal objects, such as electricity or gas, are equal to things because of their similarity to material things. The Ukrainian concept of property rights include the object of property rights that can be both corporeal and incorporeal. Thus, in accordance with Art. 316 of the Civil Code of Ukraine, the object of ownership is the thing (property). And according to Art. 190 of the Civil Code of Ukraine, property as a special object are considered a separate thing, a set of things, as well as property rights and obligations. Therefore, the concept of "thing" in Ukrainian law is widely interpreted, and includes not only objects of the material world, but also incorporeal things. Property rights and obligations are, in fact, incorporeal things, and therefore, the Ukrainian concept of ownership does not preclude the application of property rights provisions to virtual assets.

The next step in the analysis of the legal nature of virtual property is the distinction between virtual property and intellectual property, whose objects are actually property rights, that is, incorporeal things.

8 Mousourakis, G. (2015) Roman law and the origins of the civil law tradition. Switzerland: Springer.

9 Van der Walt, A. J. (2011) Constitutional Property Law. 3rd ed. Cape Town: Juta Law, pp. 114-115.

10 Erlank, W. (2012) Property in virtual worlds. PhD. Stellenbosch: Stellenbosch University, p. 216.

11 Op. cit., p. 222. 
There is no common opinion on the correlation between virtual property rights and intellectual property rights. Since virtual property, as well as intellectual property, is intangible, it is often mixed with the latter. ${ }^{12}$ In such case, the primary rights of the intellectual property owners and all related ones are governed by the End User License Agreement (EULA). However, the result of this approach is the limitation of the virtual property owners' rights by the owners of intellectual property rights. This is why the concept of virtual property has appeared. Therefore, the idea is to make difference between intellectual and virtual property.

There are also some assumptions that intellectual property is a component of virtual property, that is, intellectual property is a separate category within virtual property. Consequently, J. Gong divide virtual property into four categories: avatars, domain names, virtual movables, and intellectual property. ${ }^{13}$ However, it seems that the concept of intellectual and virtual property should not be confused, since the concept of virtual property was introduced precisely to refer to objects that do not exist in the material world but only in virtual reality.

According to J. Fairfield, online resources have nothing to do with intellectual property. On the contrary, these resources were designed to have the same characteristics as real movable things. This fact makes the ownership provisions an obvious source of regulation for such resources. ${ }^{14} \mathrm{~J}$. Fairfield's position has been supported in numerous follow-up studies. Ch. Blazer notes that the only similarity between virtual and intellectual property is that both of them relate to intangible interests, but their similarity ends there. ${ }^{15}$

Ch. Blazer analyzes features of virtual property in order to distinguish virtual property from intellectual property. According to Ch. Blazer, rivalrousness of virtual property objects make a fundamental difference between virtual and intellectual property (rivalrousness means the ability

12 Hurter, E. (2009) The international domain name classification debate: are domain names "virtual property", intellectual property, property or no property at all? The Comparative and International Law Journal of Southern Africa, 42 (3), pp. 288-289; Nelmark, D. (2004) Virtual property: the challenges of regulating intangible, exclusionary property interests such as domain names. Northwestern Journal of Technology and Intellectual Property, 3, pp. 1-7; Stephens, M. (2002) Sales of in-game assets: an illustration of the continuing failure of intellectual property law to protect digital-content creators. Texas Law Review, 80, pp. 1513-1534.

13 Gong, J. (2011) Defining and addressing virtual property to international treaties. Boston University Journal of Science \& Technology Law, 17, pp. 101-107.

14 Fairfield, J. (2005) Op. cit., p. 1046.

15 Blazer, Ch. (2006) Op. cit., p. 140. 
of an object to be controlled by only one person at a specific time - for example, by using an e-mail address, the user excludes all other persons from access to it). ${ }^{16}$ Intellectual property is not only intangible but also uncompetitive. For example, listening to a song stored in MP3 format does not in any way limit the ability of others to listen to the same song. Restrictions on the use of intellectual property arise not from the rivalrousness of such property, but from the exclusive rights guaranteed by law. Thus, the simplest and most effective way to distinguish between virtual and intellectual property is to determine whether the property is competitive in nature or only protected by exclusive rights. ${ }^{17}$

Another feature of virtual property is also the distinction between virtual and intellectual property. Persistence is an attribute of traditional property that is often lacking in intangible objects. For example, a melody is persistent (stable) only as long as it sounds. A tune is protected by intellectual property rights only after it is fixed on a tangible medium, which at the same time is the subject of traditional (private) property rights. Therefore, intellectual property is characterized as intangible and unstable. On the contrary, virtual property, despite its intangibility, is persistent (permanent). For example, a user who uses the mail service may not without reasons expect that his / her e-mails will be kept for months, even if he / she only uses the account for a few minutes per day. ${ }^{18}$

Thus, the virtual property category was designed to protect users' rights to virtual objects. However, inevitably, there are some issues connected to the rights of providers / developers of virtual worlds, platforms and more. Therefore, an important issue is the balance of users' and providers' interests.

The positions of the researchers on this issue differ. For example, J. Nelson is in favour of defending virtual world developers and against granting the users virtual rights to in-game items. He points out that virtual worlds have been created by developers for years, and they put a lot of effort into their development. Granting virtual property rights to users will inevitably reduce the developer's authority over the objects they create, which is unfair. ${ }^{19}$ In his turn, J. Fairfield notes that today it is no longer possible to dispense with the rights to virtual resources only for developers

16 Fairfield, J. (2005) Op. cit., pp. 1047-1102.

17 Blazer, Ch. (2006) Op. cit., p. 143.

18 Op. cit., pp. 144-145. 
of virtual worlds. Recently, the number of applications for theft of virtual items has increased. Thus, over 22,000 incidents of theft of virtual property were reported to South Korean police. ${ }^{20}$ So the problem is that the developers of the virtual worlds do not have enough tools to influence the offenders. Even if the developer of the virtual world has reason to sue the offender, he or she has little incentive to file such a claim. Firstly, the operator of the virtual world does not lose anything, because there was only a transition of the virtual object from one user to another. Secondly, filing a lawsuit against a hacker can draw users' attention to the security flaws that could have their accounts compromised, and this will cause developer contractual liability. Therefore, if users do not acknowledge their virtual property rights to the items they own, they will be left without due compensation. ${ }^{21}$

One solution to the problem of securing the rights of both virtual world developers and users is to distinguish different levels of "ownership" within the virtual world. In this regard, S. Abramovitch proposes to distinguish three levels of "property" in virtual worlds. The first level is the virtual world itself, which is essentially a computer code protected by intellectual property rights. The second level are objects within the virtual world, such as avatars, swords, clothing, buildings, etc. that are analogous to real-world property objects. The third level are the in-game items, which are both intellectual property and virtual property objects. For example, a virtual book is both a physical object and its content is an intellectual property right; the designer line of clothing in the virtual world is both a physical object, but the design of these garments is protected by intellectual property right. This example can also be used to distinguish between intellectual property rights that a developer has to the object he created, content and software for the virtual world, and other rights that players may have to in-game objects embodying physical objects. ${ }^{22}$

19 Nelson, J. W. (2010) The virtual property problem: what property rights in virtual resources might look like, how they might work, and why they are a bad idea. McGeorge Law Review, 41, p. 298.

20 Ward, M. (2003) Does Virtual Crime Need Real Justice? BBC News.com. [online] Available from: http://news.bbc.co.uk/2/hi/technology/3138456.stm [Accessed 21 July 2020].

${ }^{21}$ Fairfield, J. (2005) Op. cit., p. 1081.

22 Abramovitch, S. H. (2009) Virtual property in virtual worlds. Gowlings.com. [online] Available from: https://www.lexology.com/library/detail.aspx?g=5a3f3b03-a077-45d4-9981-36f713c928 20 [Accessed 21 July 2020]. 
This approach is well suited to substantiate the possibility of coexistence of virtual property of users and rights of operators of virtual worlds or other web platforms. Virtual property rights to virtual objects will be related to intellectual property rights to virtual objects in the same mode as property rights in the physical world are related to intellectual property rights in the physical world. That is, the existence of virtual property rights will in no way affect the intellectual property rights embodied in virtual items. Just an alienation of a virtual property object will not mean the transfer of intellectual property rights to another person.

Virtual property right can be defined as a specific type of ownership, the object of which are digital assets. In addition to the specifics of the object (which will always be incorporeal things), this right will be characterized by the specifics of the grounds of origin, content, protection, etc.

The emergence of virtual property rights must be linked to the creation of a virtual object that has the properties of virtual property: rivalrousness, persistence, interconnectivity. These may be an user's account, avatar, and other multiplayer game items, a social media account, domain name, e-mail, and other digital assets that meet these attributes.

The specificity of virtual property rights is that the absolute nature of the owner's authority is manifested only in relations with third parties. That is, when establishing a virtual property right, there are two types of legal relationships. Firstly, there are legal relationships between the virtual property owner and third parties, in which the owner's powers are absolute. Secondly, there are legal relationships between the virtual property owner and the provider, in which the scope of the owner's powers may be limited by the interests of the developer / owner of the platform. For instance, if the game or social network operator decides that the game or social network should cease to exist, this will be the basis for terminating the virtual property rights without further compensation to the users. In addition, the capabilities of the virtual property owner will be determined by the features of a particular platform, since its specificity may prevent certain user actions. This approach as a whole will not contradict the concept of property rights, since, despite the absolute nature of traditional property rights, it may be restricted in certain cases.

The specificity of the content of the virtual property right is determined by its object. Some powers of the owner in case of virtual property will differ in comparison to material objects. For example, the right to possess, 
which assumes the control over a thing, with respect to virtual property becomes different. As P. Palka points out, there are two options: simpler and more complex. In a simpler case, the virtual property is stored on the owner's device (computer or laptop, etc.). In this case, the owner independently controls the device, the information system, and has the actual ability to use, modify, delete the virtual object so on. In order for someone else to deprive the person of such digital possession, it is necessary to either physically select the device or enter the device through the Internet. In a more complex case, thanks to the information system architecture, more than one person has actual control over a digital object. For example, a file uploaded to the cloud is both controlled by the user and the provider. The user must have permission from the provider to control this feature. At the same time, the provider may also use, modify or delete the object. They do not do this because, first, they are committed to not touching these objects, and secondly, if they take some action on such objects, it will undermine the trust of other users, and the provider eventually may lose his customers who will switch to another provider. However, the hosts actually have these objects in possession. In this sense, digital ownership is not exclusive unlike the traditional ownership - several people can have in possession the same object at the same time. Thus, the only way to provide the protection of the users' rights to possess their digital property is to determine what providers are allowed and forbidden to do. ${ }^{23}$

From the above analysis, conducted by P. Palka, it becomes clear that the ability to use in the construction of virtual property also has its own specificity. $D$. Sheldon points out that the right to use virtual items provided to users by the license agreement is significantly restricted compared to the right to use the material thing. In addition to the restrictions in using of digital assets provided by the code, the license agreement restricts users to permissions only on certain behaviour. ${ }^{24}$

Thus, if in traditional property relations the owner satisfies his or her own interests by his or her own actions, the specificity of the virtual property relations is determined by the obligation between the provider and the user. As, on the one hand, the owner can independently use his

${ }^{23}$ Palka, P. (2017) Op. cit., pp. 160-161.

24 Sheldon, D. (2007) Claiming ownership, but getting owned: contractual limitations on asserting property interests in virtual goods. UCLA Law Review, 54, p. 764. 
or her virtual property and satisfy his or her interests without the assistance of others, but in order to exercise this power, it must first be provided by the operator, who must give the owner permanent access to the digital object.

The ability to dispose of the virtual assets will also have its own specifics, since the ability to dispose of virtual property will depend on the features of the platform and some other factors. Sometimes alienating a virtual property may not be technically possible. In other cases, the inability to alienate may be due to social reasons ( $P$. Palka cites an example of an alienation of a Twitter account owned, for example, by Donald Trump, without notifying users) ${ }^{25}$. Obviously, such cases can have detrimental consequences for society. Nevertheless, the situation when the ability to dispose of virtual property is limited by the terms of a particular platform, is negatively assessed. For example, many multiplayer games provide for a kind of domestic market where players have the right to dispose of in-game or real-currency game items. However, the alienation or exchange of accounts or the alienation of game items outside the game is prohibited. In general, the restriction on the right to dispose comes down to three cases: providers do not allow the alienation of objects for real money; providers allow the sale of virtual items for real money, but only with the use of systems created and controlled by them; providers allow the sale of some assets but forbid the alienation of others. ${ }^{26}$ This situation is estimated as a misuse of providers by their rights and should not be tolerated.

In addition, the ability to dispose of a virtual asset is specific because, unlike real-world objects, alienation of virtual objects requires the assistance of the provider or developer. That is, developers must ensure the possibility to transfer of virtual property from one person to another.

The same applies to the protection of virtual property rights: even if the court decides, for example, to require the thing from the wrongful owner and transfer it to the rightful owner, it is impossible to execute such decision without the assistance of the provider, since virtual property exists within a certain platform. In this case, either the obligation of providers to facilitate the enforcement of court decisions should be provided for, or the ability of enforcement agents to access the platform to enforce

25 Palka, P. (2017) Op. cit., p. 219.

26 Sheldon, D. (2007) Op. cit., p. 766. 
the judgment, or to provide for the enforcement of court decisions using artificial intelligence built into the platform. In addition, in the case of providers being involved in the process of enforcement of virtual property judgments, it should be taken into account that modifying the database to transfer virtual property requires some cost. The question of whom these costs will be relied upon must be addressed. It seems fair to charge offenders the costs incurred by providers in enforcing court decisions.

\section{THE CONCEPT AND LEGAL NATURE OF A SOCIAL MEDIA ACCOUNT}

Most often, the definition of social media is given from the point of view of its relation to media and publishers. Thus, T. Standage says that social media are

"two-way, conversational environments in which information passes horizontally from one person to another along social networks, rather than being delivered vertically from an impersonal central source". ${ }^{27}$

\section{J.A. Obar and S. Wildman add that social media are interactive and}

"can be characterized as a shift from user as consumer to user as participant". ${ }^{28}$

J. Samples states that social media are platforms, not publishers; they provide the means for large numbers of people to produce and consume information. ${ }^{29}$

However, there are neither legal nor doctrinal definition of a social media account as an object of legal relationships. To understand the legal nature of such object first of all we need to analyse its technical essence.

The term "social media" encompasses any online platform that allows individuals to communicate, create content and interact socially. ${ }^{30}$ Social media can include blogs, wikis, podcasts, photos and video sharing, virtual

${ }^{27}$ Standage, T. (2013) Writing on the Wall: Social Media - The First 2,000 Years. New York: Bloomsbury, p. 8.

${ }^{28}$ Obar, J. A. and Wildman, S. (2015) Social Media Definition and the Governance Challenge: An Introduction to the Special Issue. Telecommunications Policy, 39 (9), p. 746.

29 Samples, J. (2020) Why the Government Should Not Regulate Content Moderation of Social Media. Cato Institute Policy Analysis, 865, pp. 1-31. 
worlds and social networking sites, such as Facebook, Instagram, LinkedIn and Twitter. ${ }^{31}$

Technically, a user account is a relationship established between a user and a computer, network or information service. In this relationship, a user is identified by a username and password, which are optional for computers and networks, but mandatory for registrations and subscriptions to online services. ${ }^{32}$ An account can also be defined as a collection of data associated with a particular user of a multiuser computer system. Each account comprises a username and a password, and is the subject of security access levels, disk storage space, etc. ${ }^{33}$

Therefore, the conclusion can be made that a social media account (profile) is a personal page, where a user posts his or her personal information, uploads video, audio and other content, and by means of which he or she interacts with other people. The use of this page is only possible after a special procedure of authorization by creation of a username (login) and password. Thus, an account includes several elements: firstly, authentication information (which is necessary for authentication of the user by a provider and includes a username and a password); secondly, an account is linked to a database on the server provider, where information from this account is stored. This database connects a user with information available from social media.

Social media accounts have a complex structure and differ from one another depending on the opportunities given by a particular platform. Nevertheless, there are always certain elements in the structure of social media account. These are: a username and a password as a way of authorization of the user; information posted by a user on his or her personal page (content); the user's correspondence and personal data.

30 Edosomwan, S., Prakasa, S., Kouame, D., Watson, J. and Seymour, T. (2011) The History of Social Media and its Impact on Business. The Journal of Applied Management and Entrepreneurship, 16 (3), pp.79-91; Fuchs, C. (2014) Social Media: A Critical Introduction. London: Sage.

31 Naito, A. (2012) A Fourth Amendment Status Update: Applying Constitutional Privacy Protection to Employees' Social Media Use. Journal of Constitutional Law, 14 (3), pp. 849-883; Park, S. and Abril, P. (2016) Digital Self-Ownership: A Publicity-Rights Framework for Determining Employee Social Media Rights. American Business Law Journal, 53 (3), pp. 537-598.

32 Pcmag.com. (2019) User account Definition from PC Magazine Encyclopedia. [online] Available from: https://www.pcmag.com/encyclopedia/term/53549/user-account [Accessed 26 April 2020].

33 Encyclopedia.com. (2019) User account | Encyclopedia.com. [online] Available from: https://www.encyclopedia.com/computing/dictionaries-thesauruses-pictures-and-pressreleases/user-account [Accessed 26 April 2020]. 
Therefore, the legal regulation of social media accounts involves contract law provisions (Terms of Service developed by social media owners), intellectual property rights, data protection and privacy regulation, and property rights. Considering the above-mentioned, we can suggest the distinguishing of a legal regime of separate elements of the account and a legal regime of the account in general. To determine the legal nature of a social media account, we need to answer the question of whether it can be considered as an object of property or virtual property right.

As it was stated before, an object can be considered a kind of virtual property if it meets three characteristics: rivalrousness, persistence, interconnectivity. All of these could be applied to social media account. Social media account is rivalrous since it can be controlled by only one person at a specific time - the user excludes all other persons from access to it. An account is persistent as it will be kept for months, even if one only uses it for a few minutes per day and in case he or she does not use it for a long period of time. An account can also be characterized as interconnected since there is a possibility to use it together with other users who get such permission from the owner.

The grounds to consider an account to be an object of property rights could be found in the practice of the European Court of Human Rights (hereinafter referred to as ECtHR).

As it is known, the ECtHR has adopted a broad concept of property in its case law. The court stressed in its judgement in Gasus v. Netherlands ${ }^{34}$ that the notion of "possession" is not limited to physical goods. The notion "possessions" in Art. 1 of Protocol No. 1 to the Convention for the Protection of Human Rights and Fundamental Freedoms (hereinafter referred to as Convention)

"has an autonomous meaning which is certainly not limited to ownership of physical goods: certain other rights and interests constituting assets can also be regarded as "property rights" and thus as "possessions" for the purposes of this provision". ${ }^{35}$

${ }_{34}$ See Gasus Dosier- und Fördertechnik GmbH v Netherlands, Merits. (1995) Application No 15375/89, A/306-B, [1995] ECHR 7. (1995). 20 EHRR 403, IHRL 3433 (ECHR 1995), 23rd February 1995, European Court of Human Rights [ECHR]. 
Later it was adopted an autonomous interpretation of the term "possessions", according to which it has an autonomous meaning which is independent from the formal classifications in national law. ${ }^{36}$

In addition to movable and immovable things, "possession" in the ECtHR's practice encompasses property and non-property interests, such as claims and debt, court actions, company shares and other financial instruments, licenses for business, future income, intellectual property, rental and real estate rights, social benefits and pensions, professional clients and more. In general, the rights fall within the scope of Art. 1 of the Convention, if they meet three terms: significant economic value, possibility of identification in a tangible or intangible object, unconditional legal affiliation with the person concerned.

Currently, business shifts online, consequently, more and more personal webpages, blogs, and online accounts hold monetary value. According to Forbes, around 13.2 million women bloggers receive some sort of profit from their blogs, ranging from free products to a trip to Hawaii or a monthly stipend. ${ }^{37}$ Social networking sites can also generate income for an account holder. A so-called "Twitter party", where a host invites followers to tweet about a product for one hour, can bring to the host from USD 750 to USD 5000, depending on the number of participants. ${ }^{38}$ Profit generated from these sites is dependent on the number of people who click on advertisements. ${ }^{39}$

The resent case law indicates that the economic value of social media account is determined by the account's list of followers. Recently, courts have come to the conclusion that social media connections may amount

35 Douglas, Z., Pauwelyn, J., Vinuales, J. E. (2014) The foundations of international investments law: bringing theory into practice. Oxford: Oxford University Press, p. 65. [online] Available from: https://books.google.com.ua/books?id=cl9iAwAAQBAJ\&pg=PA65\&lpg=PA65\&dq= autonomous+meaning+which+is+independent+from+the+formal+classification\&source $=$ bl \& ots=y3Gm06EEaO\&sig=ACfU3U2KOQKwU-Z3h_8dHgycL3ATrmwqyg\&hl=ru\&sa=X\& ved=2ahUKEwjeqJCg8pnpAhVWr4sKHY9RCKQQ6AEwAHoECAQQAQ\#v=onepage\&q=a utonomous $\% 20$ meaning $\% 20$ which $\% 20$ is $\% 20$ independent $\% 20$ from $\% 20$ the $\% 20$ formal $\% 20$ classification\&f=false [Accessed 20 April 2020].

36 See Saghinadze and Others v. Georgia. (2010) Application no. 18768/05, Council of Europe: European Court of Human Rights, 27 May 2010. [online] Available from: https://www.ref world.org/cases,ECHR,4c04c1f22.html [Accessed 8 May 2020].

37 Larissa, F. (2012). Is Blogging Really a Way for Women to Earn a Living? Forbes.com. [online] Available from: http://www.forbes.com/sites/larissafaw/2012/04/25/is-blogging-really-a-way -for-women-to-earn-a-living-2/ [Accessed 8 May 2020].

38 Ibid.

39 LaMotta, L. (2007) How to Make Money Online. Forbes.com. [online] Available from: http://www.forbes.com/2007/11/09/microsoft-yahoo-coke-ent-tech-cx_ll_1108makemoney online.html [Accessed 8 May 2020]. 
to a customer list and, consequently, be protected as trade secrets. Relevant factors that are used to evaluate the independent economic value in a trade secret case include: the time and resources spent on generating a customer list, whether access to the information was strictly limited, and whether it would be difficult to replicate the information included in the customer list. $^{40}$

For instance, in PhoneDog v. Kravitz ${ }^{41}$ the court found that the economic value of a social media account with 17,000 followers lies in the account's list of followers and the traffic that those followers generated to the PhoneDog website because the Twitter account produces revenue from advertisers. ${ }^{42}$ In Eagle v. Morgan ${ }^{43}$ the court concluded that the employer had made a "substantial investment of time, effort and money" into creating the LinkedIn account. ${ }^{44}$ In CDM Media USA, Inc. v. Simms ${ }^{45}$, a technology marketing and media company asserted that a LinkedIn group that included 679 names of current or potential customers was a trade secret. The court denied the former employee's motion to dismiss the case because the plaintiff proved that "the membership list was a valuable secret commodity" due to the limited access and amount of time, effort, and cost the marketing and media company expended to develop the LinkedIn membership list. ${ }^{46}$

Another argument in favor of recognizing accounts as a type of property can be found in the practice of the US bankruptcy courts. As in some respects business social media accounts provide value to the business with access to customers and potential customers, bankruptcy courts have found that business accounts on social media, including pages for business run by individual employees, are property interests which are recognised as intangible assets under the Bankruptcy Code. ${ }^{47}$ Recent bankruptcy cases conclude that the administrative privileges and associated digital rights are

40 Leeson, P. A. (2016) How many \#followers do you have?: evaluating the rise of social media and issues concerning in re CTLI's determination that social media accounts are property of the estate. Catholic University Law Review, 66 (2), p. 510.

${ }^{41}$ See PhoneDog v. Kravitz. (2011) No. C 11-03474 MEJ. 2011 WL 5415612 (N.D. Cal. Nov. 8, 2011)

42 Op. cit., p. 511.

43 See Eagle v. Morgan. (2013) No. 11-4303, 2013 WL 943350, at*9 (E.D. Pa. Mar. 12, 2013).

44 Leeson, P. A. (2016) Op. cit., p. 511.

45 See CDM Media USA, Inc. v. Simms. (2015) No. 14 CV 9111. 2015 WL 1399050 (N.D. III. Mar. 25, 2015).

46 Leeson, P. A. (2016) Op. cit., p. 512.

47 See In re CTLI, LLC (2015), 528 B.R. 359, 359 (Bankr. S.D. Tex. Apr. 3, 2015); In re Borders Grp. (2011), No. 11-10614 (MG), 2011 WL 5520261, at *13 (Bankr. S.D.N.Y. Dec. 7, 2011). 
bona fide assets and business goodwill. ${ }^{48}$ Moreover, there are discussed modes of followers' estimation. Thus, Tristan Louis has suggested estimating the value of an individual user by taking the market cap and dividing it by the number of users. ${ }^{49}$ PhoneDog in his case claimed that industry standards valued each Twitter follower at USD 2.50 per month. ${ }^{50}$

Thus, an account (especially the one with many followers) does have economic value. This value could be determined by the value of followers or considering the maximum amount a consumer is willing to pay for an item in a free market economy. ${ }^{51}$ Accounts with many followers have higher demand because they are more attractive for advertising and give more opportunities to influence people. The fact that there are individuals interested in obtaining someone's account means that accounts do have value.

If we recognize that an account has economic value and, respectively, can be covered by the right to possessions in terms of the Convention, it can be qualified as a kind of property and an object of virtual property right.

\section{LEGAL ISSUES OF THE USE OF SOCIAL MEDIA ACCOUNT}

Most common issues that occur when using social media accounts are connected to business accounts and post-mortem fate of accounts.

Business social media accounts are companies' profiles created and managed by their employees. The problem could arise in case an employee, who managed such company's page, dismisses. In such case, the issue of who gets the rights to the account must be resolved. For instance, in PhoneDog v. Kravitz ${ }^{52}$, the employee, who provided social media marketing for a company was dismissed. However, he continued to use the company's Twitter account, which had 17,000 subscribers. He just changed the handle of the account from @PhoneDog_Noah to@noahkravitz. The plaintiff claimed that the Twitter password was a trade secret and its

48 Park, S. and Abril, P. (2016) Op. cit., p. 30.

49 Louis, T. (2013) How Much Is A User Worth? Forbes.com. [online] Available from: https://www.forbes.com/sites/tristanlouis/2013/08/31/how-much-is-a-user-worth/\#31bdc8b4 1c51 [Accessed 26 April 2020].

50 See PhoneDog v. Kravitz. (2011) No. C 11-03474 MEJ, 2011 WL 5415612, at *3 (N.D. Cal. Nov. $8,2011)$.

51 Investopedia. (2019) Economic Value. [online] Available from: https://www.investopedia.com/ terms/e/economic-value.asp [Accessed 13 April 2020].

52 See PhoneDog v. Kravitz. (2011) No. C 11-03474 MEJ. 2011 WL 5415612 (N.D. Cal. Nov. 8, 2011). 
continued unauthorized use was misappropriation. The court accepted that under certain circumstances a Twitter password could be a trade secret. ${ }^{53}$

In Eagle v.Morgan ${ }^{54}$, the use of the LinkedIn profile became the subject of judicial proceedings. The plaintiff, being the owner of the company, created an account on LinkedIn for professional and personal purposes. After the company was taken over by another one, the plaintiff was replaced by another manager. At the same time, the new owners of the company obtained access to the plaintiff's profile, changed the password and the photo and replaced plaintiff's name with that of the new manager. At the same time, some professional information in relation to the claimant was left in the profile, including list of contacts. On this basis, the plaintiff filed the lawsuit on several grounds, including identity theft. The court concluded that the plaintiff had proved tortious interference by her employer but failed to award any damages. ${ }^{55}$

In Ardis Health, LLC v. Nankivell ${ }^{56}$, the defendant, who provided social media marketing in the company, refused to provide access to the company's accounts after his dismissal. The court ordered him to do it as the defendant signed the agreement that information from accounts belonged to the claimant.

Thus, in situations where a dispute between the company and workers concerning business accounts might appear, it is sensible to specify in a special contract who has the rights in respect of the separate elements of the social media account - profile, access, content, followers. ${ }^{57}$ Companies should develop their own policy concerning social networks where all possible consequences regarding to the rights in relation to social media accounts of the company should be covered.

One more issue connected with social media accounts is the determination of their destiny after the user's death.

Currently possible actions with accounts in case of their owners' death are defined by internal instructions for use in search engines or social networking sites. In such internal rules consequences are defined by users

53 Park, S. and Abril, P. (2016) Op. cit., p. 5.

54 See Eagle v. Morgan. (2013) No. 11-4303, 2013 WL 943350, at*9 (E.D. Pa. Mar. 12, 2013).

55 Park, S. and Abril, P. (2016) Op. cit., p. 6.

56 See Ardis Health, LLC v. Nankivell. (2011) No. 11 Civ. 5013 (NRB). 2011 WL 4965172 (S.D.N.Y. Oct. 19, 2011)

57 Lizerbram, D. (2013) A Legal Perspective: Who Owns Social Media Profiles?. [blog] Marketo. Available from: https://blog.marketo.com/2012/08/a-legal-perspective-who-owns-socialmedia-profiles.html [Accessed 26 April 2020]. 
or by a system (for example, Yahoo! provides for removal of the account on the user's death whereas Facebook gives to users an opportunity to dispose of the account on death). At the same time, there is no legal regulation of such actions in most countries, nor there any legal provisions on the possibility to officially bequeath social media account.

However, in the USA there are already some cases of state intervention in legal regulation of inheritance of accounts. The first step in this direction was taken in 2014, when an Act to Amend Title 12 of the Delaware Code Relating to Fiduciary Access to Digital Assets and Digital Accounts was accepted. This Act determines the notion of "digital account" and "digital asset", and gives the possibility to appoint a fiduciary over a digital account or a digital asset, who may exercise all rights in digital assets and digital accounts of an account holder, to the extent permitted by law or any End User License Agreement. ${ }^{58}$ Later, in 2015, in the majority of states of the USA the Uniform Fiduciary Access to Digital Assets Act was enacted. It allows individuals to specify in their will that the executor of their estate can have access to their e-mail and social media profiles. ${ }^{59}$ The law, in fact, uses the construction of a fiduciary or trust for disposal of digital assets of a deceased person. ${ }^{60}$

In those states where the Uniform Fiduciary Access to Digital Assets Act was not enacted, companies decide themselves, whether to provide access to digital accounts of the deceased family member to his/her relatives. For example, in Yahoo's Terms of Service agreement the provisions on closure of accounts incase of the user's death are enshrined. Based on this provisions Yahoo! bans the access to the user's account in case of his or her death. Such an approach caused a lawsuit in the State of Massachusetts (in this State the Uniform Fiduciary Access to Digital Assets Act was not enacted). In Ajemian v. Yahoo!, Inc. ${ }^{61}$, the Supreme Court of the State

58 House of Representatives 147th General Assembly. (2014) An Act to Amend Title 12 of the Delaware Code Relating to Fiduciary Access to Digital Assets and Digital Accounts. House Bill no. 345. Available from: http://legis.delaware.gov/BillDetail/23219 [Accessed 26 April 2020].

59 The Conversation. (2018) Estate planning for your digital assets. [online] Available from: https://theconversation.com/estate-planning-for-your-digital-assets-90613 [Accessed 26 April 2020].

${ }_{60}$ National Conference of Commissioners on Uniform State Laws. (2015) Revised Uniform Fiduciary Access to Digital Assets Act (2015). [online] Available from: https://my.uniform laws.org/viewdocument/final-act-no-comments-33? CommunityKey=f7237fc4-74c2-4728-81c 6-b39a91ecdf22\&tab=librarydocuments [Accessed 26 April 2020].

${ }_{61}$ See Ajemian v. Yahoo!, Inc. 84 N.E.3d 766. (2017) No. 17-1005, 2018 WL 489291 (U.S. Mar. 26, 2018). 
of Massachusetts concluded that the personal representatives may provide lawful consent on the deceased's behalf to the release of the contents of the Yahoo! e-mail account. Thus, there is ambiguous situation in practice. On the one hand, Terms of Service agreements are in their essence a contract and, consequently, create binding obligations on the parties. On the other hand, the possibility of the platform to delete e-mails or profiles which are in its possession, but in fact belong to the user, established by the Terms of Service, is unfair. As mentioned in Ajemian v. Yahoo!, Inc., even if the Terms of Service agreement were fully enforceable, which would have given the Yahoo! the possibility to delete a user's account, it nonetheless could not justify the destruction of e-mail messages after a court orders that they be provided to the user or his or her personal representatives as such destruction would constitute contempt of a court order. ${ }^{62}$

The possibility of inheriting social media accounts is recognized also in European case law. Thus, the Federal Court of Justice in Karlsruhe has recently allowed inheritance of accounts in Facebook. According to the judgment, online data should be treated in the same way as private diaries or letters, and pass to heirs. The case involved the parents of a 15-year-old girl killed by a train in 2012. The deceased girl's parents wanted access to her account to try to find out whether her death had been by suicide or accident. Facebook had refused access to the account after their daughter's death, citing privacy concerns about the girl's contacts. Under its current policy, the company only allows relatives of the deceased person partial access to the account, allowing them to change the page into an online memorial or to delete it entirely. The lower German court found for the parents in 2015, supporting the claim that Facebook data was covered by inheritance law as the equivalent of private correspondence. But in 2017, an appeals court overturned the ruling, on the grounds that any contract between the girl and the company ended with her death and could not pass to the parents. The case went to the Federal Court of Justice, and her parents have now reportedly taken over the account. According to what the judge said, it was common to hand over private diaries and correspondence to legal heirs after death, and there was no reason to treat digital data any

62 Ibid. 
differently. Moreover, the court added that the parents had a right to know to whom their child, a minor, had spoken online. ${ }^{63}$

Therefore, the situation is similar to that in the USA: relatives can require online service providers to give access to the account of the deceased family member, and providers have to give such an access.

Thus, currently the fate of social media accounts directly depends on the Terms of Service, which can grant to the social media provider the right to dispose of this property. Most of them are written to allow a service provider wide opportunities in determining if digital assets are descendible and how they are to be distributed. The provisions drafted by a service provider, not an account holder, determine how digital assets are treated after an account holder's death. Thus, account holders must exclusively rely on service providers' good will in allowing any transfer of their assets at death. ${ }^{64}$ That is not contrary to the basic principles of contract law as users accept these terms by signing up to the agreement. However, recent cases in the US and Germany courts show that courts tend to protect users' (or their relatives') interests. Therefore, we can assume that in the near future some provisions of Terms of Service, which forbid authorising access to accounts or provide an opportunity to online service providers to dispose of users' accounts, will be considered as discriminatory and illegal. As Banta N.M. rightly points out,

"any contractual provision that prohibits transfer, even if procedurally valid, should be void as against public policy. Prohibiting contracts from transferring assets fundamentally alters the character of succession law, which promotes transfer guided by the testamentary intent of a decedent, and is contrary to the reason contracts were originally accepted as a means of transfer". ${ }^{65}$

She adds, that

"service providers are not focused on protecting an individual's control over assets he or she created, earned, or uploaded. Protecting an individual's control over assets or property interests is a concern of courts and

\footnotetext{
63 BBC News. (2018) Parents win rights to dead child's Facebook. [online] Available from: https://www.bbc.com/news/world-europe-44804599 [Accessed 26 April 2020].

${ }_{64}$ Banta, N. M. (2014) Inherit the Cloud: The Role of Private Contracts in Distributing or Deleting Digital Assets at Death. Fordham Law Review, 83 (2), p. 821.

65 Op. cit., p. 803.
} 
legislatures. Courts and legislatures should continue to determine whether public policy favors digital asset inheritance" ${ }^{66}$

Despite a large number of questions in the sphere of inheritance of digital assets, it is suggested to take care of digital property's, in particular, social media accounts, fate by inscription of some specific provisions in the will, having in mind, however, provisions of Terms of Service and in its limits. ${ }^{67}$

We should mention also that the European Law Institute is currently establishing a joint study group with the Uniform Law Commission in the USA to see if the Uniform Fiduciary Access to Digital Assets Act could be used as a model for European legislation. ${ }^{68}$ It means that there is likely to be a unified approach to determination of the post-mortem fate of digital assets in the world. To ensure protection and digital assets management it would be worthwhile to appoint a digital executor. Management of digital assets, including social media accounts, is possible within the framework of a trust or fiduciary, which are known, respectively, in the common law and civil law systems.

\section{CONCLUSIONS}

Despite the huge number of relations arising regarding social media accounts, no country in the world has a clear legal regulation of such relations. In order to ensure their proper regulation, it is necessary first of all to determine the legal nature of social media accounts. The analysis of the recent judicial practice and modern legal literature reveals a tendency for an account to be considered as a digital asset. Digital assets are more and more often treated as property, they are considered to be objects of property right and the theory on virtual property rights in this context becomes more and more discussable today.

Social media accounts meet all characteristics of virtual property as they are rivalrous, persistent, interconnected. They also meet all characteristics of "possession" in terms of Protocol No. 1 to the Convention for the Protection of Human Rights and Fundamental Freedoms, as they can have significant

${ }^{66}$ Op. cit., p. 829 .

67 Conway, H. and Grattan S. (2017) The "New" New Property: Dealing with Digital Assets on Death. In: Modern Studies in Property Law. Oxford and Portland, Oregon: Hart Publishing, p. 111.

68 Op. cit., p. 113 
economic value, possibility of identification in tangible or intangible object, unconditional legal affiliation with the person concerned. Notwithstanding that digital assets may not have an objective monetary value, they still could have a great deal of emotional value. From this point of view, social media accounts could be divided into business and private accounts. While the former will have primarily economic value, the latter will be characterized by greater moral value. However, that does not prevent the possibility to treat them as property, since emotional or sentimental interests in property are also taken into account in many cases. Thus, in Ark Land Co. v. Harper ${ }^{69}$, it was mentioned, that

"the economic value of the property is not the exclusive test for deciding whether to partition in kind or by sale. Evidence of longstanding ownership, coupled with sentimental or emotional interests in the property, may also be considered in deciding whether the interests of the party opposing the sale will be prejudiced by the property's sale". ${ }^{70}$

Besides, emotional harm can be compensated under tort law. Thus, preserving digital correspondence, pictures, videos, and posts for their emotional value is as important as preserving assets with monetary value. ${ }^{71}$

In case we recognise social media accounts as a type of property and objects of virtual property rights, they could get appropriate legal protection. All issues, related to the division of rights on business social media accounts, the inheritance of social media accounts, thefts of accounts could be covered by provisions on property protection. However, it would be necessary to take into account the specifics of the virtual property right while dealing with social media accounts. Thus, the usual powers of the owner would differ regarding digital assets. Such powers should be in balance with the interests of the developer / owner of the platform. This approach as a whole will not contradict the concept of property right, since, despite the absolute nature of traditional property right, it may be restricted in certain cases. Nevertheless, the provisions of the Terms of Services, which establish general rules on the use of social media account, should be balanced from the point of view of users' protection. Since owners of digital platforms are in most cases monopolists, there is a room for state

${ }^{69}$ See Ark Land Co. v. Harper. (2004) No. 599 S.E.2d 754, 761 (W. Va. 2004).

${ }^{70}$ Ibid.

${ }^{71}$ Banta, N. M. (2014) Op. cit., p. 851. 
intervention with the aim to protect consumers. Notwithstanding that Terms of Services are a private contract in their essence, they still could establish the ownership to digital assets, in particular, social media accounts. In order to ensure the possibility to exercise users' rights regarding digital assets, Terms of Service should stipulate the obligation of online service providers to assist users in the exercising of their rights. The misuse of providers by their rights should be prohibited.

\section{LIST OF REFERENCES}

[1] Abramovitch, S. H. (2009). Virtual property in virtual worlds. Gowlings.com. [online] Available from: https://www.lexology.com/library/detail.aspx?g=5a3f3b03-a077-45d49981-36f713c92820 [Accessed 21 July 2020].

[2] Ajemian v. Yahoo!, Inc. 84 N.E.3d 766. (2017) No. 17-1005, 2018 WL 489291 (U.S. Mar. 26, 2018).

[3] Ardis Health, LLC v. Nankivell. (2011) No. 11 Civ. 5013 (NRB). 2011 WL 4965172 (S.D.N.Y. Oct. 19, 2011).

[4] Ark Land Co. v. Harper. (2004) No. 599 S.E.2d 754, 761 (W. Va. 2004).

[5] Banta, N. M. (2014). Inherit the Cloud: The Role of Private Contracts in Distributing or Deleting Digital Assets at Death. Fordham Law Review, 83 (2).

[6] BBC News. (2018) Parents win rights to dead child's Facebook. [online] Available from: https://www.bbc.com/news/world-europe-44804599 [Accessed 26 April 2020].

[7] Blazer, Ch. (2006) The five indicia of virtual property. Pierce Law Review, 5.

[8] Castronova, E. (2001) Virtual worlds: a first-hand account of market and society on the Cyberian Frontier. CESifo Working Paper Series, 618.

[9] CDM Media USA, Inc. v. Simms. (2015) No. 14 CV 9111. 2015 WL 1399050 (N.D. III. Mar. 25, 2015).

[10] Conway, H. and Grattan S. (2017) The "New" New Property: Dealing with Digital Assets on Death. In: Modern Studies in Property Law. Oxford and Portland, Oregon: Hart Publishing.

[11] DaCunha, N. (2010) Virtual property, real concerns. Akron Intellectual Property Journal, $4(1)$.

[12] Douglas, Z., Pauwelyn, J., Vinuales, J. E. (2014) The foundations of international investments law: bringing theory into practice. Oxford: Oxford University Press. [online] Available from: https://books.google.com.ua/books?id=cl9iAwAAQBAJ\&pg=PA65\&lpg=PA65\&dq= autonomous+meaning+which+is+independent+from + the + formal+classification\&source $=$ 
bl\&ots=y3Gm06EEaO\&sig=ACfU3U2KOQKwU-Z3h_8dHgycL3ATrmwqyg\&hl=ru\&sa= X\&ved=2ahUKEwjeqJCg8pnpAhVWr4sKHY9RCKQQ6AEwAHoECAQQAQ\#v=onepage \&q=autonomous $\% 20$ meaning\%20which $\% 20$ is $\% 20$ independent $\% 20$ from $\% 20$ the $\% 20$ formal\%20classification\&f=false [Accessed 20 April 2020].

[13] Eagle v. Morgan. (2013) No. 11-4303, 2013 WL 943350, at*9 (E.D. Pa. Mar. 12, 2013).

[14] Edosomwan, S., Prakasa, S., Kouame, D., Watson, J. and Seymour, T. (2011) The History of Social Media and its Impact on Business. The Journal of Applied Management and Entrepreneurship, 16 (3).

[15] Encyclopedia.com. (2019) User account | Encyclopedia.com. [online] Available from: https://www.encyclopedia.com/computing/dictionaries-thesauruses-pictures-and-pressreleases/user-account [Accessed 26 April 2020].

[16] Erlank, W. (2012) Property in virtual worlds. PhD. Stellenbosch: Stellenbosch University.

[17] Fairfield, J. (2005) Virtual property. Boston University Law Review, 85. [online] Available from: https://ssrn.com/abstract=807966 [Accessed 26 April 2020].

[18] Fuchs, C. (2014) Social Media: A Critical Introduction. London: Sage.

[19] Gasus Dosier- und Fördertechnik GmbH v Netherlands, Merits. (1995) Application No. 15375/89, A/306-B, [1995] ECHR 7. (1995). 20 EHRR 403, IHRL 3433 (ECHR 1995), 23rd February 1995, European Court of Human Rights [ECHR].

[20] Gong, J. (2011) Defining and addressing virtual property to international treaties. Boston University Journal of Science \& Technology Law, 17.

[21] House of Representatives 147th General Assembly. (2014) An Act to Amend Title 12 of the Delaware Code Relating to Fiduciary Access to Digital Assets and Digital Accounts. House Bill no. 345. Available from: http://legis.delaware.gov/BillDetail/23219 [Accessed 26 April 2020].

[22] Hurter, E. (2009) The international domain name classification debate: are domain names "virtual property", intellectual property, property or no property at all? The Comparative and International Law Journal of Southern Africa, 42 (3).

[23] In re Borders Grp. (2011) No. 11-10614 (MG), 2011 WL 5520261, at *13 (Bankr. S.D.N.Y. Dec. 7, 2011).

[24] In re CTLI, LLC. (2015) 528 B.R. 359, 359 (Bankr. S.D. Tex. Apr. 3, 2015).

[25] Investopedia. (2019) Economic Value. [online] Available from: https://www.investo pedia.com/terms/e/economic-value.asp [Accessed 13 April 2020]. 
[26] LaMotta, L. (2007) How to Make Money Online. Forbes.com. [online] Available from: http://www.forbes.com/2007/11/09/microsoft-yahoo-coke-ent-tech-cx_ll_1108makemoney online.html [Accessed 8 May 2020].

[27] Larissa, F. (2012). Is Blogging Really a Way for Women to Earn a Living? Forbes.com. [online] Available from: http://www.forbes.com/sites/larissafaw/2012/04/25/is-bloggingreally-a-way-for-women-to-earn-a-living-2/ [Accessed 8 May 2020].

[28] Lastowka, G. and Hunter, D. (2004) The laws of the virtual worlds. California Law Review, $92(1)$.

[29] Leeson, P. A. (2016) How many \#followers do you have?: evaluating the rise of social media and issues concerning in re CTLI's determination that social media accounts are property of the estate. Catholic University Law Review, 66 (2).

[30] Lizerbram, D. (2013) A Legal Perspective: Who Owns Social Media Profiles? [blog] Marketo. Available from: https://blog.marketo.com/2012/08/a-legal-perspective-who-owns-socialmedia-profiles.html [Accessed 26 April 2020].

[31] Louis, T. (2013) How Much Is A User Worth? Forbes.com. [online] Available from: https://www.forbes.com/sites/tristanlouis/2013/08/31/how-much-is-a-user-worth/\#31bdc 8b41c51 [Accessed 26 April 2020].

[32] Mousourakis, G. (2015) Roman law and the origins of the civil law tradition. Switzerland: Springer.

[33] Naito, A. (2012) A Fourth Amendment Status Update: Applying Constitutional Privacy Protection to Employees' Social Media Use. Journal of Constitutional Law, 14 (3).

[34] National Conference of Commissioners on Uniform State Laws. (2015) Revised Uniform Fiduciary Access to Digital Assets Act (2015). [online] Available from: https://my.uniform laws.org/viewdocument/final-act-no-comments-33?CommunityKey=f7237fc4-74c2-472881c6-b39a91ecdf22\&tab=librarydocuments [Accessed 26 April 2020].

[35] Nelmark, D. (2004) Virtual property: the challenges of regulating intangible, exclusionary property interests such as domain names. Northwestern Journal of Technology and Intellectual Property, 3.

[36] Nelson, J. W. (2010). The virtual property problem: what property rights in virtual resources might look like, how they might work, and why they are a bad idea. McGeorge Law Review, 41.

[37] Obar, J. A. and Wildman, S. (2015) Social Media Definition and the Governance Challenge: An Introduction to the Special Issue. Telecommunications Policy, 39 (9). 
[38] Palka, P. (2017) Virtual property: towards a general theory. PhD. Florence: European University Institute.

[39] Park, S. and Abril, P. (2016) Digital Self-Ownership: A Publicity-Rights Framework for Determining Employee Social Media Rights. American Business Law Journal, 53 (3).

[40] Pcmag.com. (2019) User account Definition from PC Magazine Encyclopedia. [online] Available from: https://www.pcmag.com/encyclopedia/term/53549/user-account [Accessed 26 April 2020].

[41] PhoneDog v. Kravitz. (2011) No. C 11-03474 MEJ. 2011 WL 5415612 (N.D. Cal. Nov. 8, 2011).

[42] Saghinadze and Others v. Georgia. (2010) Application no. 18768/05, Council of Europe: European Court of Human Rights, 27 May 2010. [online] Available from: https://www.ref world.org/cases,ECHR,4c04c1f22.html [Accessed 8 May 2020].

[43] Samples, J. (2020) Why the Government Should Not Regulate Content Moderation of Social Media. Cato Institute Policy Analysis, 865.

[44] Sheldon, D. (2007) Claiming ownership, but getting owned: contractual limitations on asserting property interests in virtual goods. UCLA Law Review, 54.

[45] Standage, T. (2013) Writing on the Wall: Social Media - The First 2,000 Years. New York: Bloomsbury.

[46] Stephens, M. (2002) Sales of in-game assets: an illustration of the continuing failure of intellectual property law to protect digital-content creators. Texas Law Review, 80.

[47] The Conversation. (2018) Estate planning for your digital assets. [online] Available from: https://theconversation.com/estate-planning-for-your-digital-assets-90613 [Accessed 26 April 2020].

[48] Van der Walt, A. J. (2011) Constitutional Property Law. 3rd ed. Cape Town: Juta Law. 